\title{
As letras da cidade ou quando a literatura inventa o urbano - leitura e sensibilidade moderna na Curitiba da Primeira República
}

\author{
The city literature or when literature invents \\ the urbane - reading modern and esthesia in the \\ Curitiba of the First Republic
}

Clóvis Gruner

Pertencemos a uma época cuja civilização corre o perigo de ser destruída pelos meios da civilização.

Nietzsche

A experiência da modernidade é essencialmente urbana. Por essa razão a cidade constituiu-se, principalmente ao longo do século XIX, em paisagem privilegiada da vida moderna. Cenário de experiências, palco de inflexões, a cidade do

Clóvis Gruner é professor de História Contemporânea na Universidade Tuiuti do Paraná e doutorando em História na Universidade Federal do Paraná, Curitiba, Brasil (clovisgruner@terra.com.br).

Artigo recebido em 22 de dezembro de 2009 e aprovado para publicação em 8 de abril de 2010.

Est. Hist., Rio de Faneiro, vol. 23, no 45, p. 51-70, janeiro-junho de 2010. 


\section{Clóvis Gruner}

século XIX seria o espaço por excelência da realização da utopia moderna, representando, a um só tempo, a possibilidade de desnaturalização e de fabricação da vida. De um lado, símbolo da vitória da técnica e da ciência, ela é, além da realização de um projeto racional, espaço de construção de uma utopia cuja síntese seja, talvez, as pretensões de ordenação espacial e a busca da higiene - tanto física quanto moral - que perpassam os discursos e as práticas dos planejadores urbanos. Por outro, construtora de novas sensibilidades, ela é o emblema da capacidade humana de sobrepujar-se à natureza, fazendo avançar o progresso e a história e deixando, na sua passagem, um rastro de destruição e ruínas, sobre as quais se erigiram a cultura e a civilização coevas (Bradbury, 1989:76-82; Bresciani, 1983).

Mas qual o sentido - quais os sentidos - da cidade moderna e o que nela há de novidade, se tomarmos como parâmetro a sua congênere "pré-moderna"? Se ela não é mera continuidade, o que a caracteriza como um acontecimento capaz de estabelecer, em relação àquele espaço, seu caráter de descontinuidade? Em primeiro lugar, há o seu crescimento vertiginoso em alguns países e regiões da Europa e nos Estados Unidos, principalmente a partir dos anos de 1840, crescimento que resulta do impulso capitalista e industrial que reordena parte do Velho Mundo, tanto geográfica quanto demograficamente. ${ }^{1}$ Segundo, há uma ressignificação das suas funções, profundamente atreladas, desde então, ao seu caráter comercial e produtivo, gerador de riquezas e de capital, a ponto de podermos afirmar, a partir de Weber, que elas desempenharam um papel centrípeto no que tange a vida econômica de boa parte das sociedades europeias oitocentistas. Enfim, há o impacto na vida cultural e a emergência, a partir da experiência do "viver na cidade", de novas sensibilidades definidoras, elas próprias, do que se convencionou chamar modernidade.

O sociólogo Georg Simmel, um dos primeiros pensadores a apontar o impacto das mudanças urbanas do Oitocentos nas sensibilidades de seus contemporâneos, já refletia, em fins do século XIX, acerca da emergência de novos hábitos e costumes a partir da consolidação do fenômeno da metrópole. De acordo com Simmel, a vivência do homem urbano moderno implica a formação de uma nova percepção de si e do outro, um redimensionamento do olhar diante de uma multidão que se apresenta sem rosto, desprovida de identidade, a um só tempo sedutora e ameaçadora. A experiência da foule, anotou, acentua no indivíduo sentimentos por vezes contraditórios, mas sempre complementares (Simmel, 1976).

Os insights seminais de Simmel foram lidos com atenção e inspiraram em grande medida o trabalho de um seu conterrâneo, Walter Benjamin, que no já clássico trabalho sobre a poesia de Baudelaire como paradigma da Paris "capital do século XIX", atenta para o fato de que "o herói é o verdadeiro objeto da modernidade. Isso significa que, para viver na modernidade, é preciso uma constituição heroica". Um heroísmo que é condição de sobrevivência às pressões 
da vida moderna, "desproporcionais às forças humanas". "Compreende-se", de acordo ainda com Benjamin, "que ele [o homem] se vá enfraquecendo e busque refúgio na morte" (Benjamin, 1989:73-74). Esse heroísmo - que é também, paradoxalmente, expressão de uma impotência - resulta em parte da descontinuidade que se estabelece em relação à cultura e aos modos de vida "pré-modernos", proliferando relações que determinam não apenas uma diversidade de estilos de vida, mas inúmeras possibilidades de combinações entre eles. $\mathrm{O}$ mundo moderno põe em circulação elementos culturais que favorecem a emergência de novas significações e sociabilidades. Um dos desdobramentos mais visíveis dessa condição é o descentramento das referências e identidades, inscritas em um ritmo alucinante e lancinante, em que nada, nem ninguém, são suficientemente fixos ou estáveis.

E se a modernidade é essencialmente urbana, não nos é estranho que boa parte da literatura contemporânea seja, ela própria, não apenas produzida $n a$, mas $a$ partir da cidade, erigida muitas vezes à condição de personagem, mais que de simples cenário. Essa íntima relação entre a literatura e o urbano certamente não é casual. Desde a produção e a circulação das ideias, textos e livros, é nela que se encontram as condições favoráveis ao fomento das invenções literárias: editoras, livrarias, bibliotecas, museus, revistas etc. É nela também que os ambientes intelectuais e culturais aparecem como mais propícios ao debate e à criatividade, individual ou coletiva. As universidades, centros de cultura, cinemas, teatros e cafés, entre outros espaços, permitem e estimulam o fluxo constante de ideias, o diálogo entre diferentes línguas e culturas e a ampliação das fronteiras das experiências e experimentos estéticos (Bradbury, 1989:76).

Meu interesse neste artigo, no entanto, não é simplesmente tematizar a relação literatura e cidade ou, mais especificamente, pensar a literatura como representação da cidade, mas ler os textos literários como testemunhas fundamentais das mudanças, muitas, que ocorreram em um tempo e espaço determinados: a cidade de Curitiba de fins do século XIX e começo do XX. Mas não só isso. Minha hipótese é a de que a proliferação de textos literários, tais como crônicas e novelas ficcionais, e o seu consumo por um público leitor mais amplo contribuíram de forma significativa para a formação de uma nova sensibilidade, moderna e urbana, com toda a carga de contradições que ambos os termos carregam.

Apoiado em Lynn Hunt, que viu na leitura de romances um elemento fundamental nas mudanças sensíveis que culminaram, ao longo do século XVIII, na “invenção dos direitos humanos", entendo que a sedimentação do hábito da leitura - ele próprio "urbano" - criou "novas experiências individuais (...) que por sua vez tornaram possíveis novos conceitos sociais e políticos" (Hunt, 2009:32). Mas antes de nosso passeio literário pelas ruas curitibanas, é preciso visitar rapidamente, como turistas em excursão, outros textos e suas capitais. 


\section{Clóvis Gruner}

\section{A cidade como personagem e metáfora}

Se o século XVI viu nascer o romance moderno, com Dom Quixote, o XIX assistiu sua consolidação e o nascimento de outros gêneros literários, em grande medida frutos da popularização da imprensa. Foram os jornais, aliás, os responsáveis por criar e banalizar um novo gênero, o folhetim, que, nas entrelinhas de sua escrita previsível e teatral, nos permite ler os detalhes, nuances, personagens e mistérios das grandes metrópoles europeias (Meyer, 1996: 411-419). De suas páginas saltava um ambiente que escapava a qualquer pretensão de racionalização e planejamento. Cenário intenso, conflituoso e contraditório, a urbs da ficção folhetinesca é, mais que pretexto, a principal personagem desta escrita que respira e vive a cidade, ao mesmo tempo que lhe dá forma e vida. Sua síntese emblemática é o romance Mistérios de Paris, de Eugene Sue, publicado originalmente no Le fournal des Débats ao longo de mais de um ano - junho de 1842 a outubro de 1843.

Contemporâneas à popularização do romance-folhetim, há aquelas obras que beberam em outras fontes e circularam por outros meios e espaços, também fundamentais para se entender o imaginário forjado a partir da experiência urbana moderna, seja ela a Londres dos romances e contos de Dickens, ou a Paris dos romances de Zola e da poesia de Baudelaire. E se estes autores a abordam de maneira direta, em Edgar Allan Poe ela será sempre uma presença intensa, embora quase sempre latente. Uma das exceções é justamente o conto "O homem da multidão", que incorpora em poucas páginas os medos e inquietações característicos de seus coetâneos diante do ambiente caótico e labiríntico em que se haviam transformado os grandes centros urbanos - ou pelo menos como eles eram representados a partir de um certo imaginário, que os associavam ao perigo e à instabilidade. Nesses discursos, o ambiente citadino aparecia, não raro, como desprovido de segurança e sempre ameaçador, onde prevaleciam as paixões irracionais de uma multidão anônima e aterrorizante a habitar as suas vielas, becos e demais reentrâncias.

Contra uma multidão que aparece homogênea, sem rosto, indefinida, é preciso acionar um olhar capaz de reordenar o espaço e identificar em meio à massa as individualidades perigosas, cuja existência ameaça a ordem. Não é gratuito que a crônica e a ficção policial venham à luz neste ambiente, parte daquele aparato discursivo responsável, segundo Foucault, pela "produção da delinquência" e pelo desenvolvimento de uma "tática de confusão" que tinha por intuito criar um estado de conflito cotidiano e permanente. As "histórias de crimes" apresentavam a delinquência como algo ao mesmo tempo familiar e estranho, "uma perpétua ameaça para a vida cotidiana" (Foucault, 
1989: 250-256), daí a rápida popularidade adquirida pelas narrativas policiais, que sintetizavam, na figura do detetive, tanto o medo do caos e do estranho, quanto a urgência de tudo ver, reconhecer e ordenar - ou seja, o desejo da ordem.

A palavra escrita e impressa - policial ou não - tornou-se assim, ao longo do século XIX, elemento fundamental na tentativa de homens e mulheres de significarem, darem um sentido às mudanças tão intensamente experimentadas naquele período. E nesse redemoinho de palavras que procuravam, a seu modo, organizar a cidade - quando, na verdade, o que mais faziam era perder-se nela - a literatura ocupa um papel central. Assim como hoje voltamos a ela para vislumbrar aspectos do passado que não nos chegam por outras fontes e discursos, também os escritores e leitores pretéritos usavam da prosa e do verso para expressar sua inquietação e seu fascínio, seu encantamento e seu tremor diante da avalanche de novas sensações produzidas pela vivência diária em um mundo onde tudo o que era sólido desmanchava-se no ar.

Daí também que, em grande medida, a cidade que emerge das páginas dos livros, revistas e jornais "aparece mais como metáfora do que como lugar físico" (Bradbury, 1989:77). É que a intenção não é tanto ordenar e planejar o espaço "real" - responsabilidade do Estado e tarefa de engenheiros, arquitetos e urbanistas -, mas ordená-lo, significá-lo no interior de uma outra geografia, simbólica e imaginária. Trata-se, em suma, de construir um significado mais ou menos comum a uma gama de experiências dispersas e conflitantes, solitariamente vividas. Ao representar o urbano, a literatura forja um espaço no interior do qual é possível, sem renunciar à solidão, compartilhar e comunicar a experiência. Trata-se, então, de pensar a vida urbana moderna não como a produtora de um novo espaço público, mas, principalmente, como aquela que a um só tempo inventou e intensificou a vida privada, apresentando aquele como instável e ameaçador e transferindo para esta "o significado da vida individual", bem como os novos padrões para se avaliar o que constitui, efetivamente, os sentidos possíveis da experiência, empobrecida com a modernidade (Moretti, 2007:152).

Nunca é demais lembrar que o mesmo Benjamin que diagnosticou o esvaziamento da narração nas sociedades urbanas e modernas, apontou a emergência de outros procedimentos narrativos, que se articulavam a uma outra realidade, mais intensa e complexa que a das sociedades "tradicionais", mas que cumpriam, à sua maneira, uma função simétrica - entre eles a literatura. Mas ao fazê-lo, ela não se limita a "refletir" ou "reproduzir" a realidade a que se refere; a narrativa literária, mais que informar, cria e produz a cidade. Se a literatura moderna é uma "arte das cidades", ela certamente não a encontrou pronta; foi preciso, do verbo, inventá-la. 


\section{Clóvis Gruner}

\section{Uma cabocla cortesã}

E como essas experiências foram vividas em uma cidade - Curitiba que, capital de um estado recém-criado, mal ultrapassara, ao final do século XIX, a marca dos 50 mil habitantes? ${ }^{2}$ Certamente, não se trata aqui de compará-la às grandes metrópoles europeias. Por outro lado, independente do seu caráter "provinciano", as experiências sensíveis de que trato aqui não são quantificáveis. Não há como medir a maneira pela qual determinados grupos e indivíduos vivenciam a experiência da mudança e as sensações contraditórias e intensas produzidas em um espaço cujo sentido, afinal, não se encerra em alguma noção precária de "realidade". Trocando em miúdos, para além dos investimentos públicos na modernização urbana, interessa-me pensar, a partir de um certo discurso - o da literatura - e de um tempo específico - a Primeira República -, de que maneira a cidade foi produzida e inventada, tornada moderna. Se, em suma, entre a "cidade real" e a "imaginada" - ou entre a "física" e a "simbólica" - não existe uma dicotomia, mas sobreposições e coexistências, minha intenção é pensar a partir de que relações uma ordena, significa, atribui sentido a outra, e vice-versa. Tenciono também verificar como as diferentes formas de percepção dessas mudanças cooperam para a formação de uma nova estrutura de sensibilidade, moderna e urbana, perceptível principalmente a partir dos textos literários que circulavam pela capital paranaense.

A lista de títulos que se debruçaram sobre o período da Primeira República em Curitiba é bastante significativa. Em que pese as abordagens, fontes e métodos de análise distintos, eles parecem ter em comum a noção de que viver em Curitiba na virada do século "implicava em tomar contato com novas experiências que se apresentavam e com expectativas que se projetavam de um grau de civilização desejado" (Berberi, 1998:1). Trata-se, segundo esta historiografia, de um período intenso, marcado por transformações de toda ordem - das materiais às sensíveis - e de forte diversidade cultural e intelectual.

No que tange mais especificamente à produção literária, alguns autores (Berberi, 1998; Costa, 1999; Denipoti, 1998 e 1999; Gruner e Sereza, 2008; Iorio, 2004; Pereira, 1998) parecem estar de acordo em relação a pelo menos três fatores. Primeiro, que a intensa criação e movimentação letrada e livresca verificada nos primeiros anos do século XX vinham sendo gestadas pelo menos desde duas ou três décadas antes, com a chamada "geração simbolista". Segundo, que é praticamente impossível, tanto para os simbolistas quanto para o grupo que o sucedeu, circunscrever a produção literária a apenas um ou dois nomes - ainda que, numa geração e em outra, alguns tenham se destacado mais que outros. Tratava-se, grosso modo, de uma produção inserida em uma ampla rede de relações, seja no que diz respeito ao número de autores que assinaram textos os mais diversos- 
de poemas a manifestos, passando por crônicas, contos e novelas -, seja nos espaços ocupados por estes mesmos atores, que eram tudo ao mesmo tempo agora: escritores, poetas, cronistas, jornalistas, editores, professores, polemistas, agitadores culturais etc. Terceiro, que o esforço dos intelectuais e escritores locais produziu, pelo menos durante um período, algo além de um espelho onde mirar-se narcisicamente. Dito de outro modo,

“essa expansão possibilitou que, em primeiro lugar, a leitura fosse ampliada para um número maior de pessoas que se alfabetizaram e, em segundo, que essas leituras fossem diversificadas entre essas pessoas, assumindo um caráter extensivo, ou seja, o farto material de leitura disponível possibilitava que as leituras fossem feitas poucas vezes, podendo passar-se para outras leituras disponíveis" (Denipoti, 1998: 12).

A essas características, eu acrescentaria outra que, embora presente nos estudos sobre a literatura do período, me parece ainda não suficientemente explorada: uma atenção sensível às mudanças ocorridas no espaço público, às tensões e contradições que tal esfera comporta, bem como as possibilidades abertas, por esta literatura, a uma reflexão sobre a constituição de novos sentidos e sensibilidades. Se do ponto de vista do poder público e das novas elites urbanas, econômicas ou não, era preciso construir uma capital condizente com sua condição pretensamente moderna e cosmopolita, nada mais coerente que novas sociabilidades, bem como novos hábitos, costumes e padrões de comportamento, acompanhassem aquelas transformações. Tanto a literatura quanto a leitura ocupam aí um papel central, entre outras coisas porque seu cultivo denota a emergência de uma sensibilidade mais afinada com noções europeias de civilidade e progresso. Mas não é só. Escrever é interpretar e dar forma, pela ficção, a sentimentos, percepções, desejos e medos muitas vezes dispersos e difusos; é acolhê-los no interior de um discurso que, ao significá-los, torna legível a cidade, desenha sua fisionomia.

É principalmente nas páginas das revistas que começam a circular em Curitiba já nos derradeiros anos do XIX que encontramos as primeiras manifestações acerca do impacto da modernidade na formação das novas sensibilidades. Em crônica publicada na revista Cidade de Coritiba, autor anônimo sintetiza, de maneira exemplar, a maneira como as mudanças são recebidas e percebidas pelos seus contemporâneos:

Esta futurosa Capital augmenta a olhos vistos... Augmenta e progride... Já não é a Coritiba de 1885, nem a de 1890. Já se não 
anda pelas ruas, o chapeo na mão, cumprimentando à direita e à esquerda. $\mathbf{O}$ numero de physionomias extranhas sobreleva ao das conhecidas.

Entretanto, para os paranynphos d'este forte adolescente, Coritiba é ainda o bêbê dócil e mansinho, sem prejuízos, sem ambições, sem necessidades. Deixam-se ficar, confissos do presente e do futuro, na confortável paz do home; e o afilhado, á rédea solta, traquinas e de manguinhas de fora, vae pregando peças a uns e outros, prejudicando estes, desencabeçando aquelles, despreocupado, ignorante.

\section{(...)}

Coritiba já não é a mesma cidadesinha pacata de 1885 . Tem se desenvolvido, e, com ella, paixões torpes, ambições sórdidas, necessidades imperiosas.

O roubo, o assassínio, a velhacaria, a calumnia já não são phantasmas que apenas avultam na imaginação dos sonhadores; há portas assignaladas das garras dos larápios; cadáveres rasgados bruptalmente por ferro fratricida; compassivos illudidos, explorados pela gatunagem impune dos bilontras; homens de mérito, honestíssimos, inutilisados pela vilania bajuladora da pretenciosidade ambiciosa. ${ }^{3}$

Na crônica chama a atenção, principalmente, a observação de que o "numero de physionomias extranhas sobreleva ao das conhecidas" para caracterizar o crescimento da cidade em contraposição aqueles que insistem em vê-la, ainda, como um "bebê dócil e mansinho". A associação, que revela uma angústia sutil e um quase indisfarçável incômodo, coloca o próprio autor em uma posição ambígua frente a este crescimento. Se desdenha os ingênuos "paranhymphos" de uma já não mais pacata Curitiba, por outro vê-se forçado a admitir que o aumento no número de desconhecidos anônimos, ao tornar a cidade mais moderna, faz dela igualmente refém das paixões torpes e ambições sórdidas, como se ambos os fenômenos - a modernização e a violência - fossem absolutamente indissociáveis. E na descrição da nova paisagem urbana há lugar para o "roubo, o assassínio, a velhacaria, a calumnia", que, lembra-nos o autor, "já não são phantasmas que apenas avultam na imaginação dos sonhadores.”

Associação e sentimento semelhantes aparecem em uma crônica publicada anos depois, em outra revista, por autor que assina com o pseudônimo Higino. A exemplo da anterior, mesmo que longa, a citação merece ser lida quase que integralmente:

(...) Ella era uma caboclinha rustica, de tez morena e olhos azues. Andava a errar pelas selvas sem fim, pelas mattas seculares, 
o corpo apenas abrigado em pelles brutas de animaes ferozes, os pés descalços, acostumados a pisar espinhos.

Um dia encontraram-na assim homens da civilisação, agarraram-na, cingiram-lhe o corpo d'uma belleza selvagem, e a arisca menina sentio a primeira revolta do seu pudor offendido, que em ondas rubras lhe tingiram o rosto.

\section{(...)}

Desde esse dia Coritiba tornou-se outra: já não era a mesma matutinha submissa; seu rosto agora fino e aformoseado pelo uso constante de pomadas odorantes, tinha uns ares altivos e proprios das damas da sociedade; seu corpo, agora delgado, vestia finissimos trajes de seda pura, e seus delicados pésinhos calçavam reluzentes botinhas de verniz.

Agora ella é a altiva cortesã, a seductora princeza do Sul, a mulher que fascina, que tem encantos mil, que tem mil adoradores. ${ }^{4}$

A nova paisagem urbana que se desenhava encontra nesta crônica uma de suas melhores sínteses. Nela, seu autor recorre a uma metáfora relativamente comum para descrever uma cidade em processo de mudança: aquela que, ao compará-la a uma mulher, a sexualiza, tornando-a e tomando-a como objeto de um desejo. Mas, no caso de Curitiba, tal processo não se fez sem o recurso à força. Se desde Freud sabemos que o preço a se pagar pela cultura é a contenção de nossos instintos mais violentos, nossa pulsão de morte, nem por isso o processo pelo qual ingressamos na civilização prescindirá, ele próprio, da violência. Ao menos para o cronista curitibano, foi preciso violentar o corpo virgem, dotado de uma beleza selvagem, para que dessa violência fundadora emergisse a "altiva cortesã", não mais "matutinha submissa", mas "seductora princeza". A cidade moderna nasce violentada e impura.

Separadas no tempo por breves 15 anos, as duas crônicas revelam uma mesma imagem, ainda que a primeira apareça desprovida do erotismo pretensamente poético da segunda: Curitiba cresceu, e cresceu não apenas em população, dado estatístico que não parece ser a principal preocupação dos cronistas. O que interessa a eles, e é o objeto mesmo de ambos os textos, é o impacto deste crescimento nas sociabilidades e na sensibilidade dos curitibanos ou, mais precisamente, dos leitores curitibanos que consomem, cotidianamente, os jornais e revistas que circulam pela capital. 
Para outro cronista contemporâneo, que assinava sob o pseudônimo de Paulo Hellenos, a resposta está dada: o preço a se pagar pelo progresso é a tristeza. Em uma "croniqueta" publicada em julho de 1903 no jornal Diário da Tarde, Paulo Hellenos se pergunta: "Como explicar a tristeza de Curitiba?", e é esta indagação que move sua escrita. Curitiba, reconhece de início, é uma cidade repleta de possibilidades, das naturais às humanas, além das oportunidades que oferece aos que aqui vivem ou que para cá se dirigem. Mas, "com tantas vantagens", reflete, "reina no centro, como nos arredores da capital, um ar de profunda melancolia que, em certas horas, sobretudo, lhe dá um tom de cidade morta". Melancolia que encontra seu sinônimo quase perfeito no "silêncio" que denota a ausência do "bulicio, o arruido, a vozeria peculiares aos meios sociais em que a vida como que transborda de todos os sêres". Para Hellenos, uma das causas para a expressão taciturna até entre as crianças curitibanas deve ser buscada na "ausência de estímulos, um campo aberto a aspirações, um caminho em cujo rumo a esperança depare consôlo e animação."

Esse mesmo silêncio com que Paulo Hellenos caracteriza Curitiba, e que rendeu uma polêmica que se estendeu por páginas e semanas, reaparece quase um ano depois nas páginas do mesmo Diário da Tarde ${ }^{6}$ No novo artigo, a vida curitibana é descrita como "quasi um castigo" e, nele, as intempéries naturais parecem ser o pretexto para se falar de um cenário urbano marcado pela melancolia e, novamente, pelo silêncio:

Chuva, frio, decepções e correrias, por tudo.

O doce encanto da rua 15, a illuminura dessa Via-lactea tão bella, repleta de astros nas noites festivas de carnaval (...) tudo que nas tardes idas se apresentava como n'um céo triumphal e deliciosamente, foi transformado de um momento para outro nesse [ilegível] de aldeia sem graça, sem arte, como n'uma dolorosa sexta-feira da Paixão.

A praça Tiradentes ficou em desuso, tão cedo. ${ }^{7}$

A crônica encerra descrevendo os "raros transeuntes, tristes passantes", que frequentam a praça em desuso, "receosos de serem observados, suspeitos também de inimigos das instituições", que "esgueiravam-se ligeiramente pelas claras alamedas da praça em direções esquivas (...)”. É sobre esses mesmos passantes, parece, que se colocam a olhar outras crônicas e seus autores. Junto com o progresso, e como parte e produto dele, novos personagens entram em cena: são bêbados, jogadores, mendigos, prostitutas e seus clientes e cáftens. Em uma delas, o cronista acompanha o andar trôpego de "um retardatario da taverna que se recolhe mergulhado na inconsciencia bestial da embriaguez". 
Suas reflexões, além de carregadas de uma moral peculiar ao período, são significativas também pelo que sugerem, ainda que rápida e sutilmente, da influência das modernas teorias científicas acerca da delinquência e da criminalidade então em voga. Ouçamo-lo: "Talvez, pensei, elle nem tenha culpa desse destino horrivel; quem sabe lá, exemplar de degenerescência, anda elle a carregar o pesadissimo fardo de uma tara cruel. (...)". 8

O tom é muito parecido nas crônicas e editoriais que se reportam, por exemplo, à mendicidade e ao jogo, esse último considerado por outro cronista um "cancro que corrompe os bons costumes, depois de arruinar a fortuna." ${ }^{\text {" As imagens }}$ são outras. Se alguns cronistas optam por enfatizar o lado por assim dizer "luminoso" do progresso, aqui é a noite e seus mistérios que provocam a inquietação e a curiosidade. A face escura e obscura é explorada especialmente em duas crônicas publicadas em $O$ Paraná. Na primeira, o autor, que assina Almocreve, descreve um "entrevero formidavel" que presencia na região central, envolvendo prostitutas, seus clientes e um grupo de "melodiosos noctambulos serenateiros". A escrita, melancólica, ressalta o quanto de sombrio se esconde pelas esquinas escuras da cidade:

Como é triste e deserta a noite!

A cidade dorme envolta no seu manto de trevas como que prostrada por um profundo lethargo.

Os fócos de luz eléctrica lançam pelas travessas mysteriosas uma claridade medrosa, que parece esquivar-se a aclarar alguma scena que se occulta nas dobras da noite (...). ${ }^{10}$

A constante menção à noite nas crônicas citadas não é casual. Os esforços e investimentos por parte do poder público para modernizar especialmente a área central da capital tornam a presença em ambientes noturnos algo mais corriqueiro, daí também a vida, hábitos e personagens notívagos tornarem-se figuras e imagens frequentes nas páginas de jornais e revistas. E não é difícil imaginar o que significa para seus leitores este contato com um ambiente que, há até pouco tempo, lhes era estranho e mesmo desconhecido. Mais que palavras, são paisagens que se formam no imaginário de uma comunidade de leitores, para quem a cidade adquire uma outra dimensão e novos significados. Se o dia ilumina a cidade, tornando-a um texto cuja leitura se faz sem enigmas, os segredos ocultos nas "dobras" da noite a tornam um lugar de mistérios insondáveis e fascinantes, ao mesmo tempo que assustadores como um bom roteiro policial. As crônicas urbanas, como instantâneos, prestam- se a um papel fundamental, qual seja o de intermediar a relação dos leitores com estes novos lugares, sejam eles ruas e praças públicas, ou aqueles am- 


\section{Clóvis Gruner}

bientes onde as fronteiras entre o público e o privado se confundem, tais como hotéis e "casas de diversão" que pululam pelo centro e imediações.

Um destes lugares aparece retratado por J. Cayobá na crônica "O hotel" - no caso, um hotel sugestivamente denominado Paris, utilizado para a prática da prostituição -, que integra uma série chamada "A 'Urbs' Viciosa”, título que por si só já vem carregado de sentidos. Mas ela se torna mais significativa à medida que desenvolve uma interpretação do progresso de Curitiba, recusando-se a ver nele apenas evolução, entendida aqui no seu sentido mais comum: a de que as mudanças implicam sempre uma melhoria moral ou material, um "salto de qualidade" em relação a uma situação anterior. Progresso e vício são indissociáveis e, juntos, definem para Cayobá a ideia de perfeição:

- Vae em progresso, não ves? Quem diria que esta pacata capital de há dez annos atraz, sem cinemas, sem tavolagens doiradas e sem hoteis, havia de chegar dentro em pouco a esta perfeição...

- Perfeição? - atalhei, curioso d'uma definição cabal do conceito um tanto ambiguo.

- Pois não vês este hotel, branco pombal onde as loiras chanteuses arrulam á meia luz discreta dos boudoirs trescalantes do perfume estonteador do Houbigant e das pomadas? Pois são estas divas (...) as pombas mensageiras da civilisação e... do vicio.

(....) - São ellas as sacerdotisas do vicio e as mensageiras - para que não dizer - de costumes que, embora abomináveis aos olhos pudicos d'uma sociedade patriarchal, vinculam-se às grandes civilizações jamais comprehendias sem os grandes vicios...

(...) - Que dúvida José; hoje não se comprehende uma cidade moderna, uma urbs smartisada sem estes templos do Peccado. $^{11}$

Aqui o erotismo civilizado e exibido da "altiva cortesã" da crônica de Higino se desloca para lugares obscuros. Sua existência é sintoma de uma mudança que, por irremediável, coloca a modernidade urbana acima do bem e do mal e sobre a qual já não há mais o que lamentar: trata-se, simplesmente, de aprender a conviver com ela. A decadência moral aparece como o "outro lado" da vida moderna. Indissociáveis na pena do cronista, não há como usufruir dos benefícios de uma sem conviver com os desconfortos de outra. 
E se ao cronista soa quase natural essa associação entre vício e progresso, nem sempre e nem com todos será assim. Se para J. Cayobá uma cidade moderna se compreende também - e principalmente, arriscaria dizer - pelos seus vícios, para as elites locais e para a classe média, sedentas de tranquilidade e paz, o vício e a desordem significam uma ruptura. Restabelecer ou assegurar a ordem passa a ser uma das prioridades dos administradores públicos. Especialmente porque nas páginas dos jornais essa desordem não se restringe às contendas noturnas entre seresteiros e boêmios, ou às visitas nem sempre discretas e sutis de clientes a suas prostitutas. Não pretendo aqui explorar os editoriais e artigos em que a demanda por investimentos mais significativos na segurança pública são uma constante. Basta, para meus propósitos, afirmar que, embora em menor número, eles acompanham e são mesmo o complemento destes outros textos onde os "mistérios de Curitiba" são representados como consequência, irremediável, do processo civilizador pelo qual passava a capital - e seus habitantes - no alvorecer da República e do novo século. Ainda que por caminhos e em formas distintas, uns e outros revelam sentimentos muito próximos: a ansiedade, a insegurança e o medo diante das mudanças e do desconhecido.

\section{Um estranho automóvel}

Inquietações semelhantes às dos cronistas da imprensa impulsionaram, anos mais tarde, um grupo de autores a lançar-se em uma aventura editorial: a coleção "A Novella Mensal", depois rebatizada "A Novella Paranaense", que em um curto espaço de tempo - de 1925 a 1926 - lançou sete títulos, todos, obviamente, assinados por autores paranaenses. Tentarei aqui analisar, brevemente, um deles, o primeiro entre todos, "O automóvel n. 117... e outras novellas", assinado por Octávio de Sá Barreto, que era, além de autor, um dos empreendedores da coleção, junto com Rodrigo Junior. Estamos já em meados dos anos 20, os “anos loucos”, e não há razões para supor, da parte de Octávio de Sá Barreto e seus companheiros de empreitada, qualquer resquício de pudor quanto ao ambiente moderno que se respirava em Curitiba. Aliás, é o próprio Sá Barreto quem o diz, sem meneios, na abertura de seu livro, em um pequeno texto que simula uma entrevista do autor a um imaginário repórter: amas sobretudo...

[Repórter] - Espírito inquieto, vibrante, moderno,

[Sá Barreto]-A vertigem! A luz! O imprevisto! A vida! 


\section{Clóvis Gruner}

\section{(...)}

[R] - Mas novellas e poemas... de que feitio? Românticos? Parnasianos? Symbolistas?

[SB]-Modernos, impressionistas, século XX! O thema é susceptível de renovação... Nada de velharias poeirentas e tediosas! Amor livre, verso livre, tudo livre! Lembra-te que vivemos na era do jazz-band...(Sá Barreto, 1925:10).

E se a retórica é freneticamente moderna - afinal, vivia-se a era do “jazz-band" - o que eu proponho aqui é interrogar o quão moderna é a modernidade de Sá Barreto ou, mais especificamente, como esta modernidade é representada, ganha forma, pela ficção, em sua novela de estreia. A narrativa de $O a u$ tomóvel n. 117 inicia com uma agitada descrição de São Paulo, que aparece tomada por um movimento de aceleração de ritmos:

Sumira-se na confusão estonteadora de bondes, autos, carros e transeuntes (...) Tomou o bonde Largo de S. Bento. Lá chegando saltou e embrenhou-se no labirintho do triangulo, que é a rua S. Bento: estreita, suffocante, ornada de bellos edificios. Um vae-vem continuo de transeuntes e vehiculos empresta-lhe certa graça, certa alegria, em suma, muita attracção.

\section{(...)}

(...) São Paulo já esta habituada á neblina; entretanto, quando ella tudo avassala, a massa popular diminui um pouco. Era melhor: elle gostava mais do desaperto. (...) continuou andando, sem rumo, numa prostração de sonhador romantico. Estava ali em São Paulo, estudando Direito, sem ter tido descanso, numa peleja ardorosa de quem quer vencer (Sá Barreto, 1925:18-20).

Paremos um pouco para observar a grande São Paulo: uma metrópole de relações impessoais, um espaço onde os acontecimentos são abordados de forma a banalizar as relações entre indivíduos; porém ao mesmo tempo sedutora e ligeiramente alegre. Representada por um prisma tipicamente moderno, onde o ritmo acelerado, a sensação de sufoco, assim como o espaço labiríntico fazem parte da paisagem e da narrativa, o autor utiliza um imaginário próprio das cidades do final do século XIX e início do XX. A modernidade paulista da década de 1920, registrada por Sá Barreto, a um primeiro olhar, não difere da apresentada 
por outros literatos ou cronistas de época: um ar impessoal e "fremente" que se adequam perfeitamente às aspirações do individualismo moderno, de quem peleja ardorosamente "sem ter tido descanso", submetendo-se às privações e tensões da cidade grande com o propósito único de "vencer".

A rotina de Carlos, o protagonista, no entanto, é abalada por um entrevero típico das grandes cidades. Após presenciar um atropelamento, ele passa a se sentir perseguido pelo automóvel que provocara o acidente, uma limousine vermelha de placa número 117. Atormentado pela imagem do fatídico automóvel, ele convalesce e tem sonhos terríveis com a máquina:

Via-se numa estrada enorme, sósinho, amarrado no chão, com o ventre para o ar. Queria mover-se, não podia. Nisto ouviu, vindo de longe, um ruído pavoroso. Era o barulho produzido pelo ronco possante da hélice do motor de um automóvel... E aproximava-se... Aproximava-se... Elle não podia levantar-se, correr, sumir-se...

Começou a gritar: ninguém o soccorria. Um suor frio lhe inundava a cabeça e o corpo, latejantes. E vinha... E vinha... Um número enorme estava na sua frente: era o 117... Que horror! Agora o auto vermelho, aquella "limousine" trágica, estava a dois passos de si e... deu um grito formidavel, acabava de ser esmagado... (Sá Barreto, 1925: 25)

Convalescendo, Carlos retorna a Curitiba com a esperança de nela encontrar a paz e o sossego de que necessitava para recuperar o equilíbrio emocional que a lembrança do acidente perturbara. Afinal, em sua memória, a cidade natal se lhe apresentava sem "a inquietude das grandes cidades, que não tem o afan dos turbilhões e o barathro dos grandes centros de civilização, mas, que tem a graça, o attractivo das cidades que se estão formando, das cidades que amanhã serão, como as outras, turbulentas e infernaes!” (Sá Barreto, 1925: 44).

$\mathrm{O}$ reencontro com Curitiba, no entanto, reserva para o protagonista mais que a doçura calada das cidades ainda pacatas. Se a cidade não é ainda "turbulenta" e "infernal" como São Paulo, o próprio narrador aponta, páginas adiante, para uma mudança na paisagem que parecia ameaçar a eternidade do "céu azul" curitibano. Caminhando pela rua 15 de Novembro, Carlos se vê em meio a uma pequena multidão que o obriga a desviar do caminho original, "pois não gostava de agglomerações populares" (Sá Barreto, 1925: 49). Transitando entre fronteiras tênues, onde os limites entre a "cidade real" e a "imaginada" nem sempre são claros, Sá Barreto parece apreender, por intermédio de seu personagem, uma característica comum aos habitantes das cidades modernas e, num certo sentido, aquilo que o difere tanto de seus antepassados quanto de seus contem- 


\section{Clóvis Gruner}

porâneos "não-urbanos". Uma vez no espaço público, lugar de desordem e caos, é preciso aprender a arte da contenção das emoções, do silêncio e da discrição, que cada vez mais passam a imperar como regras de conduta e civilidade, em um mundo onde a inclinação ao esgarçamento e à fragmentação dos laços sociais tendem a transformar o outro em uma ameaça a um só tempo constante e desconhecida (Sennett, 1992: 243-271). É preciso estar atento e vigilante às nuvens que, irremediavelmente, tornarão cinza o céu "eternamente azul".

Essa imagem acompanhou todo o texto e seu protagonista. É esta urbs, contraditória, amada por sua "simplicidade", mas que já anuncia, em suas entranhas, a turbulência infernal "das cidades que amanhã serão", que salta aos olhos dos leitores das páginas das "Novellas paranaenses". Nelas, a cidade já construída e a que está por construir, a do desejo, não apenas residem no interior de uma mesma utopia, mas integram-se nela, configuram um único espaço. E por mais que se a desejasse, nem sempre a "metrópole" vislumbrada por entre as linhas dos textos é "altiva cortesã". Como todo desejo, aliás, também este é contraditório. Ora Curitiba é representada nas páginas ficcionais como sedutora, ora a imagem que dali emerge é a da "cidade monstro", ou a de uma cidade habitada por monstros.

Nesse sentido, o final da narrativa não podia ser mais significativo. Depois de apaixonar-se por uma estranha mulher, Carlos vem a descobrir que ela é o fantasma da garota cujo atropelamento presenciara em São Paulo. Tenta fugir, mas cai, ferido e desacordado, para voltar a si

(...) com o rosto pousado sobre um objecto metalico. (...) Como se fosse um idiota, fitou aquela chapa por alguns instantes. Depois deu uma gargalhada estridente: - era o numero 117. (...) Uma baba rubra coalhava-se-lhe aos cantos dos lábios, e elle poz-se a andar, cambaleando, aos solavancos, pela tétrica escuridão, fantástica, da noite, soltando gargalhadas tilintantes, gélidas, pavorosas... (Sá Barreto, 1925: 56)

Sá Barreto escreveu o conto Automóvel n.117 durante o turbulento e acelerado período de mudanças urbanas que, muito além de materiais, foram também sensíveis. Elas moldaram novos imaginários, forjaram novas percepções e sensações. No caso de Curitiba, parece mesmo ter alimentado tanto o tremor - a fascinante inquietação provocada pela modernidade - quanto o temor do desconhecido. Esse temor pode ser observado, superficialmente, tanto na metáfora do automóvel, figura emblemática do início do século XX, quanto na sua transfiguração em monstro que persegue o protagonista, da capital paulista à capital paranaense, não apenas o atormentando, mas mergulhando-o em uma espécie de transe do qual, o desfecho assim o sugere, não escapará. 
Nesse ambiente, em que se configuram novas sociabilidades, bem como novos hábitos, costumes e padrões de comportamento, tanto a literatura quanto a leitura, como já disse anteriormente, ocupam um lugar e um papel centrais. De um lado, porque seu cultivo é denotativo de novas sensibilidades e de novos habitus que são constitutivos da própria modernidade urbana. De outro, porque permitem apreender, mesmo que provisoriamente, a profunda ligação entre acontecimentos objetivos - no caso, a modernização urbana experimentada em Curitiba na transição do século XIX para o século XX - e experiências subjetivas ou, trocando em miúdos, de que maneira a realidade é apreendida, interiorizada e significada por aqueles que a vivenciam (Hunt, 2009: 38-50; Gay, 1999: 49-50).

Claro está que não pretendo aqui fazer uma "história das mentalidades" aos moldes daquela proposta e defendida há algumas décadas pela geração que, nos anos de 1960 e 70, sucedeu Braudel na liderança dos Annales. Ciente dos riscos de tomar como unívocas e hegemônicas percepções que dizem respeito a indivíduos e grupos que não são representativos de toda uma comunidade, nem por isso renuncio de todo a possibilidade de ler, nas representações contidas no discurso literário curitibano, fragmentos de sensibilidade e de um certo olhar sobre a realidade. Olhar que pode informar procedimentos de organização e significação do real que pretenderam dar sentido, para além dos limites individuais e mesmo de pequenos grupos de intelectuais, a uma dada experiência comum.

Primeiro, porque estes indivíduos e os grupos aos quais pertenciam reivindicaram o papel de porta-vozes privilegiados desta experiência. Segundo, porque por mais modernos que pretendessem ser, não conseguiram libertar-se completamente das amarras do chamado "senso comum", revelando, nas entrelinhas de seus textos, uma relação no mínimo ambígua com a modernidade urbana. Se, por um lado, a desejavam, por outro, este mesmo desejo portava a ameaça de perigos, cujo potencial de realização gerava o medo e a insegurança (Gay, 1999: 299-303). Fosse esta ameaça o "manto de trevas" da noite ou um imaginário e monstruoso automóvel de placa 117, a modernidade não se fez experimentar senão por sentimentos complexos e contraditórios, que a desejavam e temiam com a mesma intensidade. E é nessa recepção - algo conflitante, e talvez mesmo incongruente - que os curitibanos trilharam um caminho avesso ao dos versos de Drummond e recusaram ser eternos para serem, enfim, modernos. 
1. Hobsbawm informa que as principais capitais europeias multiplicaram, em poucas décadas, sua população. Londres passou de 2,5 milhões, em 1851, para 3,9 milhões de habitantes, 30 anos depois. No mesmo período, Paris praticamente duplicou sua população - de um para $1,9 \mathrm{mi}$ lhão de habitantes (Hobsbawm, 1996: 291-319).

2. Tornada capital em 1853, quando a província do Paraná se emancipou da de São Paulo, Curitiba contava, em 1900, com uma população de 50.124 habitantes. O número, modesto, ganha outro significado se visto em retrospectiva: apenas dez anos antes, a capital tinha pouco mais de $24 \mathrm{mil}$ habitantes - ou seja, em apenas uma década, sua população mais que dobrou (Boni, 1998: 11).

3. De Monoculo. Cidade de Coritiba, Curitiba, 15 de fevereiro de 1895, ano 1, n. 1 (grifos meus).

4. HIGINO. Coritiba. O Paraná, Curitiba, 15 de junho de 1910, ano 4, n. 36 (grifos meus).

Referências bibliográficas:

BARRETO, Octavio de Sá. $O$ automóvel $n$. 117... e outras novellas. Curitiba: Empresa Gráfica Paranaense, 1925 (Novella Mensal n. 1).

BENJAMIN, Walter. Charles Baudelaire: um lírico no auge do capitalismo (Obras
5. HELLENOS, Paulo. Chroniqueta. Diário da Tarde, Curitiba, 13 julho de 1903, p. 1 .

6. As respostas ao que muitos consideraram uma provocação vieram logo nos dias subseqüentes à publicação do artigo de Hellenos. É verdade que nem tudo foram farpas. Paulo Hellenos pôde contar, por exemplo, entre os que saíram em sua defesa, com o apoio de Dario Velloso, já na época um conhecido e respeitado intelectual local.

7. FLANANDO. Diário da Tarde, Curitiba, 25 de fevereiro de 1904, p. 1.

8. HELIO. Na esquina. O Olho da Rua, Curitiba, 11 de maio de 1907, ano 1, n. 3 (grifos meus).

9. O JOGO. O Paraná, Curitiba, 22 de outubro de 1910, ano 5, n. 40.

10. ALMOCREVE. As espeluncas. $\mathrm{OPa}$ raná, Curitiba, 10 de julho de 1910, ano 4, n. 37, p. 3-4.

11. CAYOBÁ. A “Urbs” Viciosa. O Paraná, Curitiba, 20 de fevereiro de 1911, ano 4, n. 45 , p. 1-2 (grifos meus).

escolhidas, vol. III). São Paulo: Brasiliense, 1989.

BERBERI, Elizabete. Impressões - a modernidade através das crônicas no início do século em Curitiba. Curitiba: Aos Quatro Ventos, 1998. 
BONI, Maria Ignês Mancini de. $O$ espetáculo visto do alto - vigilância e punição em Curitiba (1890-1920). Curitiba: Aos Quatro Ventos, 1998.

BRADBURY, Malcom \& McFARLANE, James (orgs.). Modernismo - guia geral 18901930. São Paulo: Companhia das Letras, 1989.

BRESCIANI, Maria Stella. Londres e Paris no século XIX: o espetáculo da pobreza. São Paulo: Brasiliense, 1983.

COSTA, Vidal de Azevedo. Visões ascendentes - fragmentos do olhar curitibano ao mais leve que o ar. Curitiba: Aos Quatro Ventos, 1999.

DENIPOTI, Cláudio. Páginas de prazer: a sexualidade através da leitura no início do século. Campinas: Unicamp,1999.

-A sedução da leitura - livros, leitores e história cultural - Paraná (188-1930). Tese (Doutorado em História) - Universidade Federal do Paraná, Curitiba, 1998.

FOUCAULT, Michel. Vigiar e punir: História da violência nas prisões. Petrópolis: Vozes, 1989.

GAY, Peter. A experiência burguesa da Rainha Vitória a Freud - A educação dos sentidos, vol 1. São Paulo: Companhia das Letras, 1999.

GRUNER, Clóvis \& SEREZA, Luiz Carlos. Monstruosidades sedutoras: as novellas paranaenses e a invenção do urbano.
In: GRUNER, Clóvis \& DENIPOTI, Claudio (orgs.). Nas tramas da ficção - história, literatura e leitura. São Paulo: Ateliê Editoria, 2008.

HOBSBAWM, Eric. A era do capital - 18481875. Rio de Janeiro: Paz e Terra, 1996.

HUNT, Lynn. A invenção dos direitos humanos: uma história. São Paulo: Companhia das Letras, 2009.

IORIO, Regina Elena Saboia. Intrigas $\mathcal{E}$ novelas - literatos e literatura em Curitiba na década de 1920. Tese (Doutorado em História) - Universidade Federal do Paraná, Curitiba, 2004.

MEYER, Marlyse. Folhetim - uma história. São Paulo: Companhia das Letras, 1996.

MORETTI, Franco. Signos e estilos da modernidade - ensaios sobre a sociologia das formas literárias. Rio de Janeiro: Civilização Brasileira, 2007.

PEREIRA, Luís Fernando Lopes. Paranismo: o Paraná inventado - cultura e imaginário no Paraná da I República. Curitiba: Aos Quatro Ventos,1998.

SENNETT, Richard. $O$ declínio do homem público-As tiranias da intimidade. São Paulo: Companhia das Letras, 1992.

SIMMEL, Georg. A metrópole e a vida mental. In: VELHO, Otávio Guilherme (org.). O fenômeno urbano. Rio de Janeiro: Zahar Editores, 1976.

\section{Resumo}

Como outras cidades brasileiras do período, nos primeiros anos do século XX a capital paranaense, Curitiba, passa por um significativo processo de transformações, que afetam tanto sua esfera material quanto sócio-cultural. Uma gramática é construída para nominar esse novo universo: lazer, prazer, aventura, hedonismo; mas também individualismo, estranhamento, indiferença, multidão, insegurança, risco. A intenção deste artigo é apontar as 


\title{
Clóvis Gruner
}

diferentes maneiras de ler a modernização e a modernidade e suas representações pela produção dos discursos, em especial os literários. Entendemos que são eles, especialmente, os responsáveis pelo léxico que tenta representar as novas experiências, sociabilidades e sensibilidades urbanas. Palavras-chave: literatura, cidade, sensibilidade, modernidade

\begin{abstract}
Similarly to other Brazilian cities of the period, in the first years of the 20th Century, Curitiba - the capital city of Paraná - has undergone a significant process of transformations that affected both its material and socio-cultural spheres. A grammar has been built in order to nominate this new universe: leisure, pleasure, adventure, hedonism; but also individualism, estrangement, indifference, multitude, insecurity, risk. This article's intent is to highlight the different ways of perusing modernization and modernity and their representations in the production of discourses, especially the literary ones. We understand that they are especially responsible for the lexicon that tries to represent the new urban experiences, sociabilities and esthesia.
\end{abstract}

Key words: literature, city, esthesia, modernity

\section{Résumé}

Dans les premières années du XXe siècle, la capitale du Paraná, Curitiba, comme d'autres villes brésiliennes de la même période, subit un processus de transformation importante qui affecte à la fois sa sphère matérielle et socio-culturelle. Une grammaire est construite pour désigner ce nouvel univers: les loisirs, le plaisir, l'aventure, l'hédonisme, mais aussi l'individualisme, l'aliénation, l'indifférence, la foule, l'incertitude, le risque. Le but de cet article est de mettre en évidence les différentes façons de lire la modernisation et la modernité et, aussi, ses représentations par la production des discours, surtout ceux qui sont littéraires. Pour nous, ce sont ces discours, en particulier, qui sont responsables du lexique qui tente de représenter les nouvelles expériences, sociabilités et sensibilités urbaines.

Mots-clés: littérature, ville, sensibilité, modernité 